\title{
The contribution of a clinical pharmacist to the improvement of medication at a geriatric hospital unit in Norway
}

\begin{abstract}
${ }^{*}$
The aim of the study was to use a clinical pharmacist in order to improve the medication of patients in a geriatric hospital unit. The hospital had no experience of using a clinical pharmacist before. Methods: A clinical pharmacist participated in the therapeutic team for 27 days during a 4-year period. Drug-related problems were recorded prospectively and discussed before and at the ward round. The results of the physician's decisions on the current day about potential changes in medication proposed by the pharmacist were continuously recorded. Results: The pharmacist evaluated the medication of 250 patients. At least one drug- related problem was found in $188(75 \%)$ of the patients. For these patients, the physician made 606 decisions concerning potential changes in the medication (3.2 per patient). Thirty percent (184/606) of the decisions were connected to further measurements and to the follow-up of laboratory results, mainly $(82 \%, 151 / 184)$ for cardiovascular drugs. Forty-two percent $(255 / 606)$ of the decisions resulted in the discontinuation of drugs, dosage reduction or a decision to revise the assessment at a later stage during hospitalisation. Medicines with anticholinergic adverse effects were to a great extent withdrawn. Twenty-one percent (129/606) of the decisions were made on drugs with an addiction potential: hypnotics, anxiolytics, as well as analgesics containing tramadol and codeine. The result was often $(71 \%, 91 / 129)$ dosage reduction, a change from fixed medication to medication on demand or to discontinuation.

Conclusion: Even with a modest participation of once a month, the evaluation of a patient's medication by a clinical pharmacist led to improved changes and the follow-up of the medication of the elderly.
\end{abstract}

Keywords: Pharmaceutical Services. Aged. Norway.

\author{
CONTRIBUCIÓN DE UN FARMACÉUTICO \\ CLINICO A LA MEJORA DE LA \\ MEDICACIÓN EN UNA UNIDAD \\ GERITRICA HOSPITALARIA EN NORUEGA
}

\section{RESUMEN}

El objetivo del estudio fue utilizar un farmacéutico clínico para mejorar la medicación de pacientes en un hospital geriátrico. El hospital no tenía experiencia en la utilización de un farmacéutico clínico.

Métodos: Un farmacéutico clínico participó en el equipo terapéutico durante 27 días durante un periodo de 4 años. Se registraron prospectivamente los problemas relacionados con medicamentos y discutidos durante y en la ronda clínica. Se registró continuamente los resultados de las decisiones del médico sobre los cambios posibles sugeridos por el farmacéutico.

Resultados: El farmacéutico evaluó la medicación de 250 pacientes. Se encontró al menos un problema relacionado con medicamentos en 188 (75\%) de los pacientes. Para estos pacientes, el médico tomó 606 decisiones relativas a los cambios en la medicación (3,2 por paciente). El 30\% $(184 / 606)$ de las decisiones estaban relacionadas con posteriores medidas y el seguimiento de resultados, principalmente $(82 \%, 151 / 184)$ para medicamentos cardiovasculares. El 42\% (205/606) de las decisiones produjeron discontinuación de medicamentos, reducción de dosis o la decisión de revisar la evaluación posteriormente. Los medicamentos con efectos anticolinérgicos fueron en su mayoría retirados. El 21\% (129/606) se hicieron sobre medicamentos con potencial adicción: hipnóticos, anxiolíticos, así como analgésicos con tramadol y codeína. El resultado más frecuente $(71 \%, 91 / 129)$ fue la reducción de dosis, cambio de medicamentos a dosis fija por medicamentos a demanda o discontinuación. Conclusión: Incluso con una modesta participación una vez al mes, la evaluación de la medicación por un farmacéutico clínico llevó a mejorar los cambios y el seguimiento de la medicación de los ancianos.

Palabras clave: Servicios farmacéuticos. Ancianos. Noruega.

\footnotetext{
*Turid VEGGELAND. Skien Hospital Pharmacy. Telemark Hospital. Skien (Norway). Sigurd DYB. MD. Geriatric Unit, Department of Internal Medicine. Telemark Hospital. Porsgrunn (Norway).
} 


\section{INTRODUCTION}

It is well documented that the elderly often use many drugs and do not usually have sufficient knowledge concerning the correct use of the drugs. The result often becomes polypharmacy, poor compliance, and consequently, increased morbidity and hospitalisation. A more correct use of drugs will be cost-saving for the community and may improve the patient's quality of life. ${ }^{1-4}$ On this background, the geriatric unit at Telemark Hospital wished to attach a clinical pharmacist to the therapeutic team for the evaluation of patients' medication.

The unit, with a total of 18 beds, has elective admissions only. The patients are admitted for two weeks for rehabilitation and for the evaluation of functional impairment, loss of skills and drug treatment. These are not normally patients with severe mental disorders or patients who should rather have been admitted to a long term stay unit at a nursing home.

A clinical pharmacist often has a somewhat different approach to the use of drugs and may give valuable supplementary information about for example interactions, during the physician's decision-making process concerning potential changes of and the follow-up of the medication. Outside the Nordic countries, several studies have been performed describing the benefit of clinical pharmacists in hospitals. ${ }^{5-8}$ However, in the Nordic countries, very few studies have been published. ${ }^{9-11}$

\section{METHODS}

In the period April 2000 to June 2004 a clinical pharmacist participated at the pre-round meeting and ward round in the geriatric unit on a randomly chosen day each month. The pre-round meeting is an interdisciplinary meeting where plans for the patient's treatment and for the ward rounds are made. The hospital had granted the pharmacist access to the patients' records in advance. The method of the study has been assessed and accepted by the national ethical committee under the assumption that the patients give their consent. At the ward round, the physician informed the patients of the study and the patients gave their oral consent to the pharmacist's assistance in the evaluation of their medication.

Approximately one hour before the pre-round meeting the pharmacist went through the medication and other relevant information in the patient record for one of the two patient groups in the unit. This was chosen at random. The other patient group was not used as a control group to record changes in medication without assistance of the pharmacist. None of the patients in the study group were to be counted more than once in the case of rehospitalisation at a later stage. The current medication of the patient, both that which was previously initiated and any changes made so far during the hospitalisation, was evaluated with regard to potential drug-related problems, table 1. ${ }^{12,13}$ Problems concerning drug information were not part of the study. Proposals concerning monitoring (measurements of serum concentrations, laboratory samples and other examinations to be able to optimise the drug treatment, directly or indirectly) were made in cases where the medical records did not give any information on whether the samples or examinations had already been ordered by the physician, or in cases where the results from these examinations had not been assessed.

The results of the physician's decisions on the current day in relation to potential changes in medication proposed by the pharmacist were continuously recorded by the pharmacist according to a classification system prepared for this purpose, table 1. The further follow-up of the decisions on consequent days or after the patient's discharge from the hospital was not a part of the study. The relevant drug was recorded and classified according to the Anatomical Therapeutic Chemical (ATC) Classification System.

\begin{tabular}{|c|c|}
\hline Drug-related problems & The outcome: changes in the medication on the current day \\
\hline $\begin{array}{l}\text { Unnecessary drug, not optimal drug used, drug interaction, } \\
\text { adverse drug reaction, follow-up samples or other examinations }\end{array}$ & $\begin{array}{l}\text { Drug was permanently withdrawn } \\
\text { Discontinuation is to be considered at a later stage }\end{array}$ \\
\hline $\begin{array}{l}\text { Dosage too high, drug interaction, adverse drug reaction, follow-up } \\
\text { samples or other examinations }\end{array}$ & $\begin{array}{l}\text { Dosage reduction (incl. change from fixed medication to } \\
\text { medication on demand) } \\
\text { Dosage reduction is to be considered at a later stage (incl. } \\
\text { change from fixed medication to medication on demand) }\end{array}$ \\
\hline $\begin{array}{l}\text { Need for additional drug, not optimal drug used, } \\
\text { follow-up samples or other examinations }\end{array}$ & $\begin{array}{l}\text { New prescription } \\
\text { New prescription is to be considered at a later stage }\end{array}$ \\
\hline $\begin{array}{l}\text { Dosage too low, drug interactions, follow-up samples or other } \\
\text { examinations }\end{array}$ & $\begin{array}{l}\text { Dosage increase (incl. change from medication on demand to } \\
\text { fixed medication ) } \\
\text { Dosage increase is to be considered at a later stage (incl. change } \\
\text { from medication on demand to fixed medication) }\end{array}$ \\
\hline Not optimal drug formulation & $\begin{array}{l}\text { Simplification of number of doses (e.g. transfer to modified } \\
\text { release presentations) }\end{array}$ \\
\hline Risk of adverse drug reaction or drug interaction & Further follow-up by monitoring samples or other examinations \\
\hline $\begin{array}{l}\text { Inappropriate or incorrect documented drug name, dose, route } \\
\text { and/or dosage time }\end{array}$ & $\begin{array}{l}\text { Improved registration in the medication card, to reduce } \\
\text { misunderstandings }\end{array}$ \\
\hline $\begin{array}{l}\text { Unnecessary drug, need for additional drug, not optimal drug } \\
\text { used, dosage too high or low, adverse drug reaction, drug } \\
\text { interaction, follow-up samples or other examinations }\end{array}$ & $\begin{array}{l}\text { Prescription unchanged because the phamacist got new } \\
\text { information or the patient unwilling to change medication }\end{array}$ \\
\hline
\end{tabular}




\section{RESULTS}

Altogether, the pharmacist was present at the geriatric unit for 27 days during the study period, and the medication of 250 patients was evaluated for potential drug-related problems. None of the patients expressed any doubt in allowing the pharmacist to participate in the evaluation of their medication. An average of six minutes was used for each patient to record drug-related problems, before the pre-round meeting. The pharmacist used all relevant information about each patient which was systematically collected in the medical record: the card with current and previously changed fixed medication and on demand, the results of examinations and laboratory samples, the medical history, clinical risk factors, diseases and symptoms. A medication history was not performed.
For 188 of the patients (75\%), at least one drugrelated problem was identified. The mean age of the 188 patients was 81.6 years (range 59-95 years); 136 females and 52 males. At all except the three last occasions, the same physician, the geriatrist, participated. In addition, a pre-registration house officer and also occasionally a senior house officer were present. The physicians had the same understanding of the drug-related problems as the pharmacist. For these 188 patients, the physician made 606 decisions (mean 3.2 per patient) regarding potential changes to the patient's medication based on the proposals from the pharmacist (table 2). Table 3 shows the 20 most frequently involved drug groups.

\begin{tabular}{|l|l|}
\hline $\begin{array}{l}\text { Table 2. Physician's decision (\%) to change the patient's medication on the current day ( } \mathrm{n}=606), \\
\text { based on drug-related problems proposed by the pharmacist }\end{array}$ \\
\hline Monitoring, further follow-up & 30.4 \\
\hline Medication discontinued & 15.3 \\
\hline Dosage reduction (incl. change from fixed to on demand) & 13.5 \\
\hline Prescription unchanged & 11.6 \\
\hline Discontinuation is considered & 8.4 \\
\hline Improved registration in the medication card, to reduce misunderstandings & 5.0 \\
\hline Dosage reduction is considered & 4.8 \\
\hline New prescription & 4.6 \\
\hline New prescription is considered & 2.0 \\
\hline Dosage increase (incl. change from on demand to fixed) & 2.0 \\
\hline Simplify no. of dosages & 2.0 \\
\hline Dosage increase is considered & 0.5 \\
\hline
\end{tabular}

\section{DISCUSSION}

The absence of a control group in the study did not allow us to know how many changes in medication were made without the pharmacist's participation, and if the clinical pharmacist actually increased the number of changes in medication. However, there was no doubt from the physician's point of view that the contribution by a clinical pharmacist actually improved the patient's medication.

Our study has focused on the physician's decisions on the current day based on drug-related problems proposed by the pharmacist, rather than on the types and numbers of drug-related problems. Behind every single decision there may be several different drug-related problems. For example, high dosages, interactions, adverse effects, laboratory measurements and examinations may lead to the decision of dosage reduction. A classification system was prepared for this study, owing to the lack of an appropriate method (table 1). Australian scientists have published a somewhat different classification of physicians' decision of drug-related problems. ${ }^{14}$ No attempt has been made to assess the clinical significance of changes for a single drug. Further follow-up of the decisions on consequent days or after the patient's discharge from the hospital was not included in the study. The study will not give answers to the essential patient outcomes: to prevent, cure, arrest or slow diseases or symptoms. But the pharmacist contributes to the general patient outcomes by improvement of the drug therapy.

\begin{tabular}{|c|c|}
\hline Hypnotics (N05C) & 74 \\
\hline Diuretics (C03) & 56 \\
\hline Anxiolytics (N05B) & 36 \\
\hline Analgesics (N02) & 34 \\
\hline Renin-angiotensin agents (C09) & 33 \\
\hline Beta blocking agents (C07) & 28 \\
\hline Antianemics (B03) & 27 \\
\hline Antiinflammatory non-steroids (M01) & 26 \\
\hline Cardiac glycosides (C01A) & 26 \\
\hline Drugs for acid related disorders (A02) & 23 \\
\hline Antipsychotics / neurolepics (N05A) & 22 \\
\hline Drugs for obstructive airways (R03) & 19 \\
\hline Antithrombotics (B01) & 19 \\
\hline Vitamins (A11) & 19 \\
\hline Antidepressants (N06A) & 18 \\
\hline Minerals (A12) & 16 \\
\hline Antidiabetics (A10) & 15 \\
\hline Systemic corticosteroides ( $\mathrm{H} 02)$ & 14 \\
\hline Lipid modifying agents (C10) & 13 \\
\hline Calcium channel blockers (C08) & 13 \\
\hline
\end{tabular}

At least one drug-related problem was identified in $75 \%$ of the patients and a mean of 3.2 potential changes in medication were undertaken per patient. This is in accordance with a multi-centre study performed at six departments of internal medicine and two departments of rheumatology at five other Norwegian hospitals. ${ }^{11}$ In this study, at least one drug-related problem was identified in $81 \%$ of the patients. In the study by Pretsch and co-workers, drug-related problems were identified in $80 \%$ of the 
patients at a lung department. ${ }^{9}$ Most proposals of changes were made for central nervous system drugs and cardiovascular drugs (table 3). This is in accordance with other studies ${ }^{15-18}$, and reflects the frequency of use of these drugs in the elderly.

Nearly half $(42 \%, 255 / 606)$ of all the pharmacists proposals on the current day have resulted in either the discontinuation of medication or in dosage reduction, or a decision to make this assessment at a later stage during the hospitalisation (table 2). A direct comparison of these results with data from other studies is difficult as there are differences in the processing and presentation of the results. In the study by Viktil and co-workers, $24.7 \%$ of the patients in a geriatric unit received drugs unnecessarily and a non-optimal dosage was the most frequently reported problem. ${ }^{17}$

Nearly one third $(184 / 606)$ of the physician's decisions resulted in an increased need for further monitoring and the follow-up of clinical data, e.g. measurements of drug concentrations in serum, measurements of electrolytes, creatinine, uric acid, INR, blood glucose, iron status, and blood pressure. The cardiovascular drugs (ATC groups B and C) dominated $(82 \%, 151 / 184)$, with diuretics on top with 35 of 184 decisions, followed by reninangiotensin drugs, digitalis and antithrombotic drugs.

Drugs with anticholinergic effects are particularly unfavourable in the elderly, in particular with regard to cognitive function. ${ }^{19}$ These drugs, such as tricyclic antidepressants, sedative antihistamines and conventional neuroleptics, were therefore to a great extent withdrawn.

Most proposals were made concerning benzodiazepines (hypnotics and anxiolytics), table 3 . These drugs, as well as tramadol and codeinecontaining analgesics, were the drugs for which discontinuation or dosage reduction was most frequently performed or planned to be performed at a later stage during the hospitalisation (91 of 129 decisions, $71 \%$ ). The discontinuation of medication was performed in cases where the patient was using low doses or in case of concomitant use of several benzodiazepines. These are drugs with a potential of addiction which lead to a general overconsumption, but also give increased tiredness, increased tendency to fall and the risk of cognitive failure. The pain regimen was also evaluated with regard to the improvement of pain relief.
Even if there initially was an interdisciplinary agreement concerning the drug-related problems, $11.6 \%$ of the physician's decisions still resulted in an unchanged prescription (table 2). This can be explained by new information about the patient being forthcoming during the pre-round meeting and ward round. But the main reason was that many patients chose to maintain their original prescription themselves in spite of the information concerning adverse effects. The number of patients was unfortunately not registered in the study. The drugs involved are known to have an addiction potential, with hypnotic drugs as the most frequent (17/70), as well as anxiolytics and analgesic drugs. Hospitalisation is in itself a new situation for the patient making it even more difficult to change this type of medication in the elderly who may suffer from complex diseases and have problems concerning their social network. Further work with a gradual dosage reduction and a possible withdrawal was therefore addressed in the physician's final report to the family physician. In the study by Pretsch and co-workers, $10 \%$ of the drug-related problems were not taken into account at the preround meeting, mainly because the physician did not agree with the pharmacist. ${ }^{9}$ In that study, however, the pharmacist did not participate in the ward round, and thus any possible objections by the patient against changes should be added.

\section{CONCLUSIONS}

In summary we conclude that a clinical pharmacist contributes to a more correct medication of the elderly, even with the modest contribution such as participation in the pre-round meeting and the ward round one day per month. The study may support the argument for the gradual introduction of a clinical pharmacy service, as this is not widely accepted in most hospitals in Norway.

\section{ACKNOWLEDGMENTS}

Nurses and physicians at the Geriatric Unit, Telemark Hospital, Norway.

\section{CONFLICT OF INTEREST}

None declared. No external funding sources declared.

\section{References}

1. Ebbesen J, Buajordet I, Erikssen J, Brørs O, Hilberg T, Svaar H, Sandvik L. Drug related deaths in a department of internal medicine. Arch Intern Med. 2001;161:2317-23.

2. Moore N, Lecointre D, Noblet C, Mabille M. Frequency and cost of serious adverse drug reactions in a department of general medicine. Br J Clin Pharmacol. 1998;45:301-8.

3. Kjustad L, Klemetsdal B, Pape J. Adverse effects of drugs in the elderly - reasons for hospitalization. [in Norwegian] Tidsskr Nor Lægeforen 1987;107:551-2.

4. Ernst FR, Grizzle AJ. Drug-related morbidity and mortality: updating the cost-of-illness model. J Am Pharm Assoc. 2001;41:192-9.

5. Calvert RT. Clinical pharmacy - a hospital perspective. J Clin Pharmacol. 1999;47:231-8.

6. Leape LL, Cullen DJ, Clapp MD, Burdick E, Demonaco HJ, Erickson JI, Bates DW. Pharmacist participation on physician rounds and adverse drug events in the intensive care unit. JAMA 1999;282:267-70. 
7. Wood J, Bell D, Clark C. Pharmaceutical care in patient medical records - putting a system of documentation into practice. Pharm J. 1998;260:717-9.

8. Boorman S, Cairns C. Another way forward for pharmaceutical care: a team-based clinical pharmacy service. Pharm J. 2000;264:343-6.

9. Pretsch P, Hertzenberg SW, Humerfelt S. Clinical pharmacist improves the use of drugs in a hospital ward. [in Norwegian, english summary] Tidsskr Nor Lægeforen 2004;124:1923-25.

10. Olsson A. [Cooperation increase the quality in the health care.] [in Swedish] Läkemedelsvärlden 2001;105:22-3.

11. Blix HS, Viktil KK, Reikvam A, Moger TA, Hjemaas BJ, Pretsch P, Vraalsen TF, Walseth EK. The majority of hospitalised patients have drug-related problems: results from a prospective study in general hospitals. Eur J Clin Pharmacol. 2004;60:651-8.

12. Cipolle RJ, Strand LM, Morley PC. Pharmaceutical care practice. New York: McGraw-Hill, 1998: 82-3.

13. Strand LM, Morley PC, Cipolle RJ, Ramsey R, Lamsam GD. Drug related problems: their structure and function. Ann Pharmacother. 1990;24:1093-7.

14. PROMISe. Phase One Final Report. UTAS School of Pharmacy. Pharmacy Guild of Australia, Research Tender, RFT 2003-01. http://beta.guild.org.au/uploadedfiles/Research_and_Development_Grants_Program/Projects/2003-504_fr.pdf

15. Straand J, Rokstad KS. Elderly patients in general practice: diagnoses, drugs and inappropriate prescriptions. A report from the Møre and Romsdal Prescription Study. Fam Pract. 1999;16:380-8.

16. Linjakumpu T, Hartikainen S, Klaukka T et al. Use of medications and polypharmacy are increasing among the elderly. J Clin Epidemiol. 2002;55:809-17.

17. Viktil KK, Blix HS, Reikvam A, Moger TA, Hjemaas BJ, Walseth EK, Vraalsen TF, Pretsch P, Jorgensen F. Comparison of drug-related problems in different patient groups. Ann Pharmacother. 2004;38:942-8.

18. Ruths S, Straand J, Nygaard HA. Multidisciplinary medication review in nursing home residents: what are the most significant drug-related problems ? The Bergen District Nursing Home (BEDNURS) study. Qual Saf Health Care 2003;12:176-80.

19. O'Keeffe ST, Lavan JN. Clinical significance of delirium subtypes in older people. Age Ageing 1999; 28: 115-9. 